\title{
Insight
}

\section{Social-ecological Resilience and Biodiversity Conservation in a 900-year- old Protected Area}

\author{
Adrian C. Newton ${ }^{1}$
}

\begin{abstract}
Protected areas are increasingly being recognized as coupled social-ecological systems, whose effectiveness depends on their resilience. Here I present a historical profile of an individual case study, the New Forest (England), which was first designated as a protected area more than 900 years ago. Uniquely, a traditional pattern of land use has been maintained ever since, providing a rare opportunity to examine the resilience of an integrated social-ecological system over nine centuries. The New Forest demonstrates that over the long term, coupled social-ecological systems can be resilient to major internal and external shocks, including climate change, mass human mortality and war. Changes in governance had the greatest impact on the reserve itself, with two major crises identified in the mid-19th and 20th centuries. Resolution of these crises depended on the formation of alliances between local people and external partners, including the general public, a process that was supported by improvements in visitor access. Over a timescale of centuries, this social-ecological system has been highly dynamic in disturbance regimes but relatively stable in land use patterns. However, the factors underpinning resilience have changed over time. This case study suggests that for protected areas to be effective over the long term, social structures and institutions as well as environmental processes require adaptive capacity.
\end{abstract}

Key Words: biodiversity conservation; effectiveness; protected area; resilience; social-ecological systems

\section{INTRODUCTION}

Protected areas (PAs) represent the most important approach for conserving biodiversity. The extent of the global PA network continues to increase, with nearly 133,000 areas now designated, representing $12 \%$ of the Earth's terrestrial surface (Butchart et al. 2010). Parties to the Convention on Biological Diversity recently committed themselves to raise this figure to $17 \%$ by 2020 (Normile 2010). Given the strong dependence of conservation strategies on PAs, and the substantial investments made in managing them, it is important to understand the factors influencing their effectiveness (Gaston et al. 2008). The need for this understanding is urgent, given that a large number of PAs are currently under threat (Carey et al. 2000, Chape at al. 2005).

Relatively few direct measures of the effectiveness of PAs are available (Craigie et al. 2010). Previous analyses have focused on the management processes (Hockings et al. 2006) and coverage (e.g., Rodrigues et al. 2004) of PAs, but these provide little evidence of whether biodiversity conservation goals are actually being achieved. Reviews of case studies and remote sensing analyses have generally indicated that PAs are effective at reducing deforestation within their boundaries (DeFries et al. 2005, Naughton-Treves et al. 2005, Nagendra 2008), but such analyses may fail to capture population declines of individual species (Craigie et al. 2010). Very few studies have examined the effectiveness of PA networks in terms of species populations and trends (Brooks et al. 2009). Craigie et al. (2010) provide an example for 78 PAs in Africa, which revealed an average $59 \%$ decline in population abundance of 69 large mammal species between 1970 and
2005. Similarly, Estes et al. (2006) documented declines of up to $60 \%$ in three mammal species since the mid-1980s in the Ngorongoro Conservation Area in Tanzania. These examples highlight the value of long-term biodiversity trends for evaluating PA performance.

If PAs are to be effective, then they will need to be resilient. In other words, they will need to be able to absorb disturbance while maintaining their function, by maintaining the capacity to reorganize and adapt to any disturbances that occur (Gunderson 2000). As noted by Bengtsson et al. (2003), PAs are subjected to both natural and human-induced disturbances at various scales, but it is the intensification of disturbance arising from human activity that is their principal threat (Chape at al. 2005). Approaches to PA management are therefore required that enable conservation objectives to be achieved while ensuring that human needs are met. This might be achieved by viewing PAs as parts of dynamic landscapes, in which human activities are an integral element (Bengtsson et al. 2003). This is consistent with a recently developed paradigm for PAs, in which meeting the needs of local people is a central component (Phillips 2003). Features of this new paradigm include management for socioeconomic objectives as well as biodiversity conservation, as illustrated by the development of community-based and collaborative approaches to PA management (Lockwood et al. 2006).

In order for such approaches involving local people to be successful, they need to be based on an understanding of the resilience of PAs as integrated social-ecological systems. Progress has recently been made in understanding the complexity and behavior of such systems. For example, Liu 
et al. (2007) profile six case studies from different parts of the world, indicating how coupled systems display nonlinear dynamics with reciprocal feedback loops, thresholds, time lags, and effects of historical legacies on current conditions and on their resilience. While the development of theory is at an early stage, Anderies et al. (2006) highlight the value of the resilience approach for understanding the dynamics of such systems, which could potentially guide interventions to improve their long-term performance. Key findings made to date suggest that social-ecological systems mainly demonstrate nonlinear dynamics that result in multiple stability domains, and that their dynamics tend to conform to linked adaptive cycles at multiple scales (Gunderson and Holling 2002, Anderies et al. 2006). However, these characteristics are not necessarily features of all socialecological systems (Brand 2009).

Carpenter et al. (2005) examine how the resilience of socialecological systems might be evaluated in practice, recognizing the need to infer it indirectly from surrogates or proxies (Holling 1973, Walker et al. 2006). Methods that have been used previously to develop resilience surrogates include stakeholder consultation, model exploration, and historical profiling (Carpenter et al. 2005). Following the suggestions made by Carpenter et al. (2005), I present a historical profile of an individual case study, the New Forest, UK (Appendix 1). This area was first designated as a PA more than 900 years ago, and has maintained a traditional pattern of land use ever since. The New Forest therefore provides a rare opportunity to examine the resilience of an integrated social-ecological system over a timescale of many centuries. Following Carpenter et al. (2005), I use historical profiling to identify distinct regimes, and then analyze transitions between them to examine system dynamics and their implications for PA effectiveness. Finally, I identify lessons learned, to indicate how long-term resilience of other PAs might be achieved in practice.

\section{HISTORICAL TIMELINE}

The New Forest was designated as a Royal Forest by King William I in 1079 (Tubbs 1968). The creation of the Forest was aimed primarily at conserving deer as an exclusive resource for the King, and imposed serious penalties for any breaches of the Forest Law, such as poaching (Tubbs 1968, 2001). The Law also protected the woodland and other natural vegetation on which the deer depended. The earliest surviving legal boundary of the Forest dates from 1217-18 and remained largely unchanged until 1964 (Tubbs 2001). This legal status severely restrained the expansion of settlements and conversion of land cover to pasture or cropland, and supported pastoral land use, which still persists today. Traditional land uses or "rights of common" (Appendix 2) were legally recognized in 1698 (Tubbs 2001).

During the over 900 years of its existence, the New Forest has experienced a number of external shocks that have impacted on its functioning as a social-ecological system, and which have even threatened its existence altogether. The Medieval period, for example, experienced major crises in public health, including the European Famine of 1315-21 and the Black Death of 1346-53, which led to widespread human mortality and socioeconomic instability (Campbell 2010). These events were succeeded by a period (1550-1850) of significant climate change referred to as the "Little Ice Age", characterized by lower winter temperatures throughout northwest Europe (Brazdil et al. 2005). Campbell (2010) has highlighted the role of positive and negative feedback mechanisms between natural and human processes that underpinned the major socioeconomic impacts of these events, such as the development of immunity and quarantine systems in the case of the Black Death. Their specific impacts on the New Forest are not well documented, although there is possible evidence of abandonment of agricultural land following the Black Death (Tubbs 2001).

Other major events affecting the New Forest, which are better documented, primarily result from changes in how it was governed. A series of laws were introduced from its inception as a Royal Forest in 1079 to its designation as a National Park in 2005 (Table 1). Primarily these reflect the long-term conflict between the interests of the monarchy and the rights of local people ("commoners", Appendix 2), which the monarchy repeatedly sought to regulate through the introduction of successive legislation. Two events are considered here in greater detail, for the insights they provide into the processes underpinning the resilience of the system. Both were significant crises, which resulted in major political interventions and transitions in governance.

The first of these is the 1851 Deer Removal Act, which marked the formal end of Royal ownership of deer. Over time, the monarchy had shifted its interest from deer to the exploitation of timber in the silvicultural "Inclosures", from which commoners' livestock were excluded. The 1851 Act can therefore be seen as continuing a process established through the preceding Acts of 1542, 1698 and 1808, which resulted in increasing areas of land being excluded from commoning activity and assigned to timber production. The demand for timber increased markedly after 1630, principally for building the ships of the British Navy (Tubbs 2001). The 1851 Act not only terminated the Royal rights to deer, but stipulated that they should be "removed". While the reason for this was cited as reducing impacts on surrounding private lands, this was essentially a pretext for enclosing substantial areas of common land as "compensation" to the monarchy (Kenchington 1944). In this way, the area available to commoners was reduced, and the area available for silviculture increased. At the same time, the rights of many individual commoners were removed (Kenchington 1944).

The ultimate aim of the monarchy was apparently to remove Forest Law from the New Forest ("disafforestation") (Stagg 
Table 1. Historical profile of the New Forest (based on Kenchington 1944, Tubbs 1968, Newton 2010a, Smith and Burke 2010, Tubbs 2001). Note that an Act of Parliament refers to a statute or law enacted by the national government.

\begin{tabular}{|c|c|}
\hline Date & Historical significance \\
\hline $\begin{array}{l}1079 \text { The designation of the New Forest } \\
\text { as a Royal Forest by King William I. } \\
1542 \text { Act }\end{array}$ & $\begin{array}{l}\text { Introduced Forest Law, which imposed the monarch's exclusive ownership of deer and other } \\
\text { game and aimed to protect their habitat. Regulated traditional land uses. } \\
\text { Creation of the post of Surveyor General of the King's Woods to increase their commercial } \\
\text { function. This established the basis for the future exploitation of woodlands for timber, for the } \\
\text { "profit of the King". }\end{array}$ \\
\hline $\begin{array}{l}1698 \text { Act for the Increase and } \\
\text { Preservation of Timber in the New } \\
\text { Forest } \\
1808 \text { Act of the Increase and } \\
\text { Preservation of Timber in Dean and }\end{array}$ & $\begin{array}{l}\text { First large-scale efforts at establishing tree plantations, through the creation of Inclosures from } \\
\text { which livestock were excluded. The Act also gave statutory recognition to common rights, but } \\
\text { resulted in conflicts with commoners over loss of grazing land. } \\
\text { Provided for Inclosure of a further } 6000 \text { acres of common land, aimed at reducing the extent of } \\
\text { commoning activity }\end{array}$ \\
\hline
\end{tabular}

New Forests

1845 Opening of London to Dorchester railway, which passed through the New Forest

1851 Deer Removal Act

Construction of the railway increased recreational access to the New Forest, and colonization by a monied middle class. Income from sale of land was used to finance drainage activities, aimed at agricultural improvement.

Relinquished the interest of the monarchy in the deer, which were heavily culled. As compensation, 10,000 acres were enclosed for establishment of timber plantations in Inclosures, which together with imposition of Forest Laws, provoked large-scale revolts among commoners and gentry. Resulted in large-scale introduction of exotic conifer plantations and drainage works.

1877 New Forest Act

No further enclosure creation allowed, and no further Inclosures permitted other than those granted under previous Acts. Reconstituted the Verderers Court to administer common rights and commoning activities, free from the influence of the monarchy.

1914-1918, 1939-1945 First and Second Forest intensively managed for timber production. Extensive areas of native woodlands felled World Wars during 1914-1918, which were then converted to exotic conifer plantations. Large tracts of land used for airfields, firing ranges, and food supplies in the Second World War.

1923 Forestry (Transfer of Woods) Act Forestry Commission takes over responsibility for management of New Forest from the monarchy. As a consequence of national forest policy, this resulted in successive attempts to convert native woodlands to exotic conifer plantations, exploit native woods commercially, and enclose more land.

The New Forest Act 1949 Act set out requirement for Forestry Commission to maintain drainage and scrub control for grazing interests, which led to significant drainage between 1965-1986. Created additional Inclosures (2005 acres).

The New Forest Act 1964 Alteration of the boundary and addition of fencing and cattle grids to help control livestock movement and prevent accidents. Introduced obligation for Forestry Commission and Verderers to give due regard to nature conservation interests. Granted permission to carry out silvicultural interventions in native woodland.

Woodland crisis 1968-1971 Plans developed for extensive clearcutting and commercial exploitation of native woods, which led to a public outcry. Ministers Mandate (1971) subsequently introduced, declaring that unenclosed woods were to be conserved "without regard to timber production objectives", and prevented further coniferization of Inclosures.

The New Forest National Park Establishment Order 2005 New Forest designated a National Park, implementing a recommendation made 14 years previously. Also designated as a Special Area of Conservation (SAC), under the EU Habitats Directive.

1992). The 1851 Act therefore represented a major threat to traditional land use patterns in the New Forest, and ultimately to its biodiversity value. The Act sparked a major revolt among commoners, who became organized by creating the Commoners Defence Association. Significantly, local private landowners also opposed the Act, and formed the New Forest Association to organize opposition and petition Parliament (Tubbs 2001). Both organizations are still active today. The campaign that they conducted mobilized public support, notably including academics, artists, and naturalists, to increase political pressure. Public awareness of the value of the New Forest had been greatly increased following construction of a railway to the area in 1845, which improved accessibility (Kenchington 1944). The publicity campaign and political lobbying were eventually successful, leading to the 1877 New Forest Act, which prevented further enclosure of 
common land and strengthened the rights of commoners (Table 1).

A second major crisis occurred at the end of the 1960s. The Forestry Commission (the national forest service) took over responsibility for managing the New Forest in 1923 (Table 1). Under their aegis, in accordance with national forest policy, timber production became the primary management goal. Many native broadleaved woods were subjected to silvicultural intervention and extensive areas were converted to plantations of exotic conifers, with a consequent reduction in habitat value (Tubbs 2001). Plans were developed to virtually eliminate native tree species from the Inclosures, through a process of extensive clearcutting. Leakage of these plans, together with an attempt to commercially exploit unenclosed woods, brought the crisis to a head. A public outcry increased the political pressure for change, which led to direct intervention by the relevant Government Minister (Pasmore 1977). In 1971, he issued a Mandate to the Forestry Commission that specified the policies that they must follow, which stated that unenclosed woodlands were to be "conserved without regard to timber production objectives", and that conversion of broadleaf trees to conifers in the Inclosures should cease (Tubbs 2001). This Mandate represents an important landmark in the history of the New Forest, as it established for the first time that it should be regarded as "natural heritage", and that the priority for management should be conservation "of its traditional character" (Tubbs 2001).

\section{SYSTEM DYNAMICS}

Analysis of the resilience of a social-ecological system can be informed by the identification of stable states and the factors influencing transitions among them (Gunderson 2000, Walker et al. 2002). As in other grazing dominated systems (Gunderson 2000), multiple stable states can be identified in the New Forest based on the dominant plant forms. The principal semi-natural vegetation types are broadleaved woodland, heathland, acid grassland, scrub (or shrubland) and mire (or marshland). These can be viewed as relatively stable states over short timescales, although both heathland and grassland will tend to undergo succession to woodland, typically through an intermediate stage of scrub development (Figure 1). Mires are potentially stable over centuries or even millennia, and woodland may represent a stable state over similarly long timescales (Tubbs 2001). Grazing (or browsing) pressure is the principal form of disturbance influencing vegetation composition and structure, although fire, wind, vegetation cutting, and drainage are also influential. These forms of disturbance modify the transitions between vegetation types (Figure 1).

The disturbance regime of the New Forest is highly dynamic. This is illustrated by the fluctuations in the numbers of grazing animals that have occurred over time. In the past, deer densities would have been much higher than currently; for example, around 8000 fallow and red deer were estimated to be present in 1670 (Putman 1986). The number of fallow deer was reduced from around 6000 animals in 1800 to virtually zero, as a result of the cull following the 1851 Act; since then, numbers have recovered to around 1700 today, a number that is regulated by culling (Figure 2). The numbers of ponies and cattle depastured on the Forest have also varied continuously (Figure 2). The reasons for this variation are not always clear, but factors include fluctuations in livestock prices, outbreaks of animal disease, and restrictions in grazing activity resulting from imposition of Forest Law (Tubbs 2001). Over the last 200 years, there has been a general shift from deer to livestock, and from cattle to ponies (Figure 2, Appendix 2).

The variation in numbers of grazing animals has had major impacts on the vegetation. For example, Kenchington (1944) cites evidence of an increase in scrub cover following the decline in deer numbers in the 1850s. Based on an analysis of the age structure of woodlands, Peterken and Tubbs (1965) suggested that three principal phases of active tree regeneration have occurred over the past 300 years (1649-1764, 1765-1850 and 1858-1923), which were related to the fluctuations in grazing pressure and the incidence of heathland burning. The third of these phases was again attributed to the decline in deer numbers after 1851. The decline in livestock numbers that occurred during World War II (Figure 2) also led to an increase in tree regeneration (Peterken and Tubbs 1965). However, the linkage between animal numbers and tree regeneration is complex; evidence suggests that some phases of high rates of tree regeneration have coincided with periods of high grazing pressure (Newton et al. 2010).

In addition to the impacts of grazing animals, the New Forest has been subjected to a number of other forms of anthropogenic disturbance arising from other traditional land uses (Appendix 2), which have similarly varied in intensity over time. These uses declined in the $19^{\text {th }}$ and $20^{\text {th }}$ centuries, particularly after World War II, representing a shift away from subsistence agriculture. The reduction in the traditional cutting and burning of heathland by commoners has been compensated by an increase in management by professional staff. Following the 1949 Act (Table 1), the Forestry Commission was required to undertake scrub control for grazing interests. From 1949-1965, a total of 800-1200 ha of heathland were burnt annually, which was reduced to an annual figure of around 400 ha thereafter (Tubbs 2001). Since 1982 , about $10 \%$ of this area has been cut rather than burnt (Newton 2010a). Increasingly, over time, the emphasis of heathland management has focused on maintaining its conservation value as habitat, as well as providing forage for grazing animals.

Despite the variation in disturbance regime, the total area of different vegetation types has remained fairly constant over 
Fig. 1. Schematic diagram indicating the different ecosystem states and transitions in the New Forest.

Note that narrow arrows indicate successional changes, broad arrows indicate transitions induced by different forms of disturbance, which may be anthropogenic in origin. Some management interventions aimed at habitat restoration are not illustrated here; for example mire communities can potentially be restored by reducing drainage, and heathland communities can be restored by removal of conifer plantations. Mire represents bog or marshland, whereas scrub is dominated by shrub vegetation, and heathland is characterized by woody ericaceous plants.

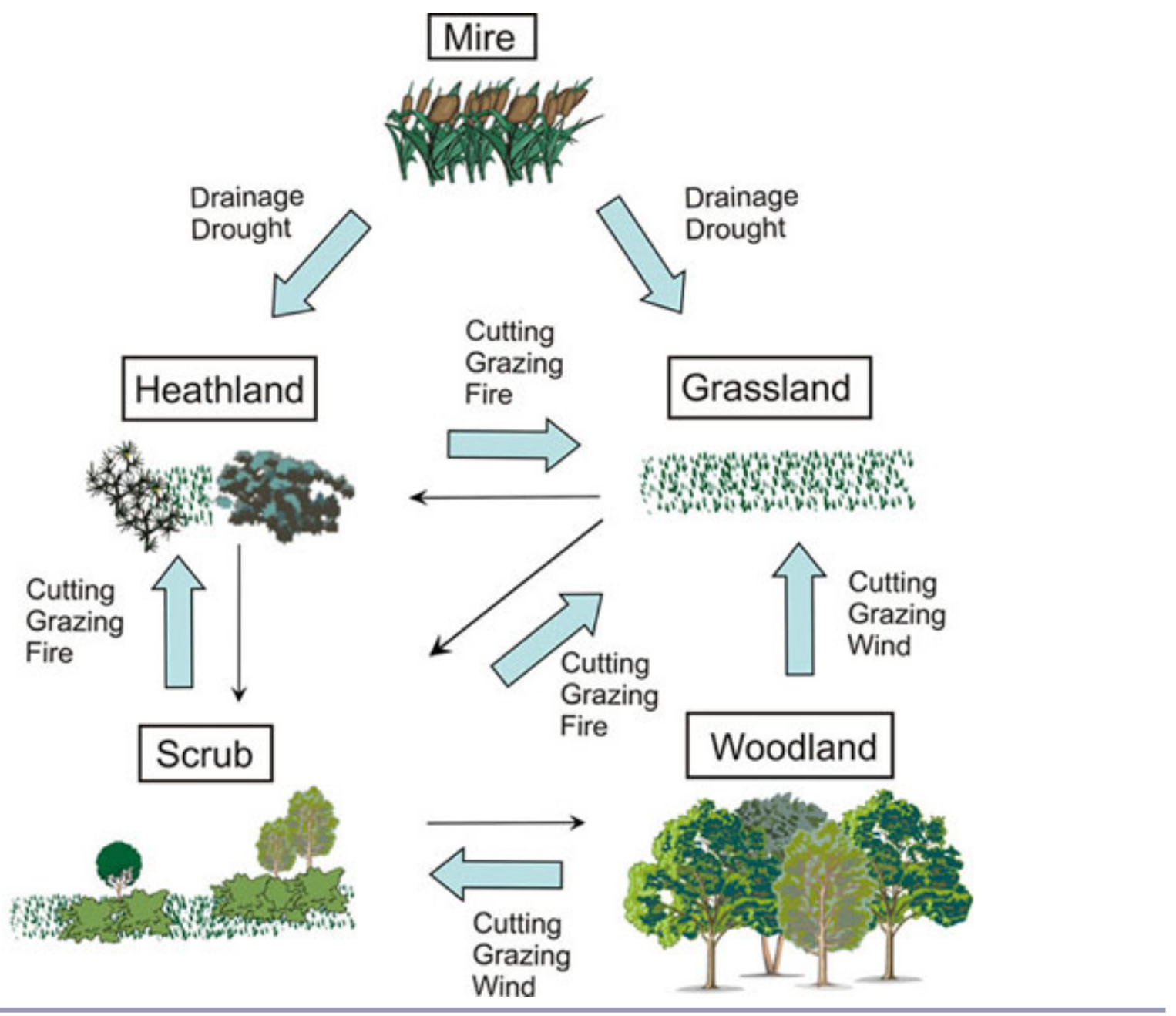

time. Analysis of historical maps dating back to 1759 indicates that between 1789 and 1868, approximately 200 ha of unenclosed woodland were lost, as the margins of some woodland patches retreated (Tubbs 2001). A number of small additional woodland areas were also converted to heathland, scrub and grassland, through fire, cutting, and grazing. However, these losses were compensated by subsequent woodland expansion after the mid-19 ${ }^{\text {th }}$ century (Tubbs 2001). In total, woodland area increased by 517 ha between 1867 and 1963 (a gain of some 21\%), as a result of successional processes (Small and Haggett 1972).

\section{PROTECTED AREA EFFECTIVENESS}

The New Forest is of exceptional importance for biodiversity, as reflected in its many designations; for example, it is recognized as internationally important under the EU Habitats Directive for the presence of nine habitats (Newton 2010b). The species richness of many groups is high, sometimes exceptionally so. For example, more than two thirds of the British species of reptiles and amphibians, butterflies and moths, fish, bats, dragonflies, and damselflies are found in the New Forest (Newton 2010b). Even for those groups that are less well represented, at least one sixth of all British species have been recorded in the area. In every group considered, the 
New Forest is home to species of national conservation concern, and in some groups, the numbers of such species are substantial; for example, the New Forest has 155 vascular plant species, 264 butterflies and moths, and 142 lichens (Newton $2010 b$ ). The area is not characterized by especially high endemicity; rather, the New Forest can perhaps best be viewed as a refuge for species that were formerly more widespread and abundant, but have declined elsewhere (Rand and Chatters 2010). This is attributable to the maintenance of low-input pastoral patterns of land use that have declined both in Britain and throughout much of mainland Europe. It is this pattern of land use, relatively free from agricultural improvement and intensification, which accounts for the extensive areas of seminatural habitats that characterize the New Forest today, on a scale that is now unique in lowland England. These characteristics can be attributed to the maintenance of commoning activity (Appendix 2) over a period of centuries.

Fig. 2. Temporal dynamics in the number of large mammals in the New Forest (based on data presented by Tubbs 2001 and Newton 2010b). Dotted line, fallow deer; dashed line, cattle; continuous line, ponies. Note that the relative abundance of these three types of animal has been inverted during the past 200 years.

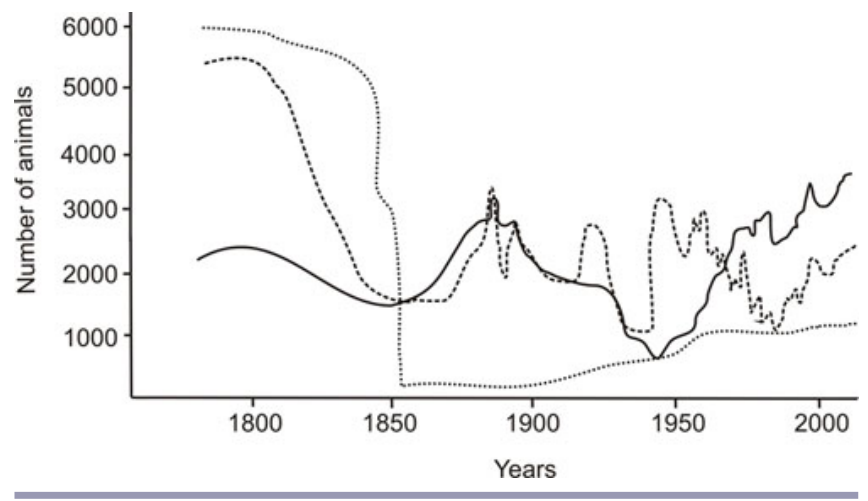

However, some losses of biodiversity have occurred over the past nine centuries. Here, I examine the evidence for such losses in relation to historical events. Evidence for the extirpation of species in antiquity is scant, although some significant losses must have occurred. Prior to 5500 years B. P., a number of mammals that subsequently became extirpated or extinct would likely have been present in the area, including elk (Alces alces), lynx (Lynx lynx), aurochs (Bos primigenius), brown bear (Ursus arctos), beaver (Castor fiber), wolf (Canis lupus) and wild boar (Sus scrofa). Evidence suggests that only the latter two species might have persisted beyond 1000 (Yalden 1999). The wolf appears to have become extirpated by the early $14^{\text {th }}$ century in England, having been hunted as vermin (Yalden 1999). Fitter (1959) reports that Charles I (1600-1649) attempted to reintroduce the wild boar to the New Forest, suggesting that the species had been hunted to extirpation prior to this date. The boar was again eliminated from the Forest during the English Civil War (1642-1651). A number of bird species similarly became extirpated in England in antiquity, some of which may have been present in the New Forest, including the Dalmatian pelican (Pelecanus crispus), the Eurasian eagle owl (Bubo bobo), the Eurasian crane (Crus crus), and the white-tailed eagle (Haliaeetus albicilla). There are records of eagle owl and white-tailed eagle being shot in the New Forest in the mid- $19^{\text {th }}$ century, and the crane is still recorded as an occasional passage migrant (Snook 1998).

More detailed information is available on losses that have occurred within the past 150 years (Newton 2010a). In total, at least 170 species have been lost from the New Forest during this period (Table 2). This estimate is necessarily uncertain; many species are difficult either to locate or to identify, and might be rediscovered by future survey work. The estimate might be conservative, as information on many species groups (particularly the most speciose) is lacking. The number of species that have been extirpated varies between different groups; losses of butterflies and moths are particularly high, but significant losses also appear to have occurred in lichens, saproxylic beetles, and fungi (Table 2). Despite such uncertainty, the available evidence suggests that inappropriate management represents the principal factor responsible for loss of biodiversity in the New Forest, and accounts for most of the species losses that have occurred in recent history (Table 2 ). Much habitat is currently in relatively poor condition (Newton 2010a), primarily as a result of management interventions undertaken during the $20^{\text {th }}$ century. Specific examples include the widespread drainage of wetlands, scrub clearance, and conversion of native woodlands to conifer plantations, particularly after the 1949 Act.

The case of Lepidoptera deserves particular consideration, as a high proportion of documented species losses have occurred within this group (Table 2). Oates (1996) notes that for more than 100 years, the New Forest was viewed as the best area for Lepidoptera in Britain; no other single area is associated with such a high proportion of the national fauna. Following construction of the railway in 1845 , the area became very popular among collectors of butterflies and moths, which developed into an important local industry. Although overcollection may have been a factor in the loss of at least two species (Oates 1996), the main cause of the decline in Lepidoptera was a change in the grazing management of the Inclosures.

Herbaceous plants increased substantially in abundance following the deer cull in 1851, providing food resources for the insects. Extensive tree felling in New Forest woods during both World Wars and the subsequent widespread establishment of conifer plantations had a major impact on the woodland flora, to the detriment of Lepidoptera. The vigorous clearing of understory vegetation, undertaken as part of forest 
Table 2. Declines and losses of different species groups in the New Forest believed to have occurred within the past 150 years, and associated causes (threats). Based on information presented in Newton (2010 a,b), synthesized from a number of sources.

\begin{tabular}{ll}
\hline \hline Species group & Trends \\
\hline Birds & At least three species lost during the last \\
& century. While some species (such as nightjar- \\
& Caprimulgus europaeus and woodlark- Lullula \\
& arborea) are stable or increasing, others (such \\
& as Dartford warbler- Sylvia undata, snipe- \\
& Gallinago gallinago, curlew- Numenius \\
& arquata, and redshank- Tringa totanus) are \\
& declining. \\
& Red squirrel (Sciurus vulgaris) was extirpated \\
& in the 20 $0^{\text {th }}$ century. No evidence of species \\
Mammals & losses in other mammalian groups. Insufficient \\
& data to determine trends in threatened species \\
& (e.g. bats).
\end{tabular}

Reptiles and amphibians

Fish

Invertebrates Dragonflies and damselflies Saproxylic beetles

Butterflies and moths

Other invertebrates

Vascular plants Insufficient data to determine trends. Some extirpations are likely to have occurred as many rare species have not been recorded for a long time, e.g., New Forest cicada may now be extirpated. Groups such as Orthoptera appear to have undergone significant declines.

One extirpation. Some evidence of historic declines in some species; others appear stable. At least five species believed to be extirpated; 27 further species not reported in past 25 years. Insufficient data to determine trends, although some species appear to have declined. General decline of many species in recent decades; 124 species believed to have been lost.

One species known to have been extirpated in the middle of the $20^{\text {th }}$ century: summer lady'stresses (Spiranthes aestivalis), which was exterminated by over-collecting and habitat drainage. Little evidence of declines in species, although few monitoring data available and impacts of human activity uncertain.

\section{Threats}

Species losses attributable to habitat loss and possibly climate change. Causes for declines in species often unclear, but may include inappropriate habitat management (e.g., Dartford warblerSylvia undata, sparrowhawk- Accipiter nisus), disturbance from human recreation (e.g., ground-nesting birds), climate change, and nest predation (e.g., Montagu's harrier-Circus pygargus).

Red squirrel was previously hunted as vermin (Lovegrove 2007), but was extirpated by 1947 (Tubbs 1968), through competition with, and disease from introduced grey squirrels (Sciurus carolinensis) (Natural England 2010). Some forest management interventions may be negative (e.g., tree felling and holly pollarding) for bat species. Possible disturbance from recreation. Common toad declines may be caused by fungal disease.

Inappropriate heathland management (burning) responsible for loss of sand lizard (Lacerta agilis). Main threat to reptiles is inappropriate heathland management (e.g., burning). History of catchment modification and drainage likely to have had negative impacts on fish populations, but evidence limited. Current management interventions, including woody debris accumulation in streams and physical modifications to stream channels, can have both positive and negative effects.

Drainage actions and scrub development responsible for species loss.

Extirpation caused by scrub clearance, and forestry/ commoning activities involving the felling of large, old trees.

Increased levels of herbivore grazing and browsing, particularly in the Inclosures, leading to a loss of structural diversity and food availability. Greater intensity of management for grazing (burning, reseeding, scrub clearance). Direct destruction of habitat caused by forestry operations (e.g., conifer planting, management of rides). Economic pressures driving land use at the Forest margins (e.g., urban development, pony paddocks, lack of support for traditional woodland management).

Changes to the grazing regime and management of the heaths and woodlands are likely to have had a detrimental effect on many insect species and their habitats. Increase in grazing intensity since the 1960s is a particular issue, especially in Inclosures. The intensification of farmsteads within the Forest and the loss of small rotationally managed fields must also have had a negative effect on the Forest, as throughout the wider countryside. Inappropriate ride management and widespread scrub clearance likely to have negative impacts.

Invasion by exotic water plants (e.g., Crassula helmsii) is probably a major threat to flora associated with ponds. Other invasive species such as Rhododendron similarly pose a threat to terrestrial vegetation. In the $20^{\text {th }}$ century, forestry practices involving creation of new plantations and conifer establishment in ancient woodland undoubtedly caused enormous damage. Management practices encouraging grazing within the Inclosures during the second half of the $20^{\text {th }}$ century led to negative impacts on flowering plants. 
Lichens

Fungi

Bryophytes
Few monitoring data available. Most uncommon species appear to be stable. However, some are clearly declining and some extirpations appear to have occurred. A total of 13 species were recorded from New Forest woods in the $19^{\text {th }}$ century and have not yet been refound, and may therefore be extirpated. In addition, four leafy species recorded since 1967 appear to have been lost and a further four are declining and rare.

Few monitoring data available. Little evidence of declines. Extirpations hard to evaluate although 18 species of conservation concern have not been seen in the past 50 years and may be extirpated.

Four species of liverwort have apparently been extirpated. Most species generally stable.
The spread of holly (Ilex aquifolium), and hence increased shade, in the past 150 years is the most significant issue. Pollution is another significant factor, especially of sulphur and nitrogen. This may be responsible for difficulties in colonizing rather than direct poisoning of the mature thalli. Death of trees has also caused loss of colonies.

Substantial losses of semi-natural woodland through felling and establishment of exotic conifers in the $20^{\text {th }}$ century must have had a major deleterious impact on fungi. Other threats include deadwood removal, and possibly also commercial collecting and climate change.

Some species threatened by scrub invasion.

x.

management practice during this period, was another contributing factor. By 1960, populations of most woodland butterflies had collapsed (Oates 1996). After the fencing of the Forest boundary in 1964, livestock densities increased, resulting in an increase in grazing pressure and penetration of livestock into the Inclosures. In the early 1970s, many of the Inclosures were thrown open to livestock through removal of fences. As a result, the butterfly fauna was devastated, as nectar sources were removed by grazing (Oates 1996).

\section{DISCUSSION}

The survival of the New Forest as a PA over more than nine centuries is exceptional. It is one of a number of Royal hunting reserves that were established in Europe, and bears some similarity to other examples such as Bialowieska (Poland) and Fontainebleau (France), although both of these were established more recently. With its prime importance as a source of deer and then timber, the New Forest was a "managed resource protected area" (IUCN Category VI) for much of its history (Lockwood et al. 2006). However, of the few Royal hunting reserves that survive, this is the only one that has maintained its medieval pastoral economy. It is therefore unique. However, its very uniqueness provides some insights into the conditions required for a PA to survive as a socialecological system over the very long term.

The maintenance of its pattern of land use depends first and foremost on the legal protection afforded by its status as a Royal Forest, attributable to its high value for populations of game animals. Its survival also reflects the marginal value of the land for crop cultivation, as a result of its poorly drained, nutrient-poor soils, in common with many other protected areas (Lockwood et al. 2006). However, it is the long-term maintenance of traditional approaches to land use that is most striking. At one level, the New Forest provides an example of the successful long-term defense of traditional land use rights by local people against external demands on their resources, particularly by the monarchy. Secure land use rights and tenure are widely recognized to be essential features of sustainable approaches to natural resource use (Lockwood et al. 2006), but one of the key lessons of the New Forest is that these rights may have to be defended repeatedly, over a period of centuries.

The principal threat to the existence of the New Forest was the 1851 Deer Removal Act, which ultimately aimed at a process of removal of Forest Law (Kenchington 1944). This would likely have resulted either in the land being transferred to private ownership, or being entirely converted to another form of land use such as plantation forestry. Such fates befell most other Royal Forests in England (Bathe 2010), as well as much other common land (Short 2008). The challenge to the status of the New Forest was very nearly successful, and was only averted by a sustained public and political campaign in which newly created NGOs were highly involved, a pattern that was repeated in the subsequent crisis in the late 1960s. This highlights the importance of forming broad alliances among different constituencies of supporters in order to defend a reserve against external pressures. While it is now recognized that the formation of alliances is of fundamental importance to effective conservation (Margoluis et al. 2000, Salafsky et al. 2002), the example of the New Forest indicates that this has long been the case. In addition, it highlights the limitations of local governance structures in countering external pressures, as intervention by national politicians was required to resolve both crises.

For any PA to be effective, the factors responsible for biodiversity loss will need to be addressed. Each of the principal vegetation types (woodland, mire, heathland, and scrub) with which species of national or international conservation importance are associated, are of significant conservation value (Newton 2010a). The ecological process 
of succession is therefore a potential cause of biodiversity loss, because if the process were allowed to continue, most of the area would become woodland and species associated with heathland, scrub, and grassland habitats would be lost. Maintenance of high biodiversity value in the New Forest is therefore dependent on management actions designed to counteract successional processes, as in many other locations in the UK (Sutherland 2000). A key feature of the New Forest is that traditional land uses, namely cutting, burning, and grazing, generally coincide with the interventions needed to maintain biodiversity value through the maintenance of successional habitats. It is for this reason that maintenance of traditional land use patterns is an integral part of current management plans (Newton 2010a), and that the New Forest can genuinely be considered as an integrated social-ecological system. Populations of many species of conservation concern are dependent on continuing interventions from humans or their grazing animals for their survival. The New Forest therefore illustrates the fact that PAs are most likely to be effective if the social components of the system undertake actions that prevent biodiversity loss, by addressing causal factors.

Analysis of recent biodiversity trends indicates that the New Forest has not been entirely effective in preventing biodiversity loss, with approximately one species extirpated per year over the past century and a half. Detailed information on species losses from PAs is often lacking (Gaston et al. 2008), and consequently there are few other examples with which to compare this figure. In U.S. protected areas, Parks et al. (2002) reported that the percentage of large mammals lost per year ranged from zero to 0.21 , whereas Newmark (1995) documented 29 extirpations of mammal species in 14 parks in western North America since their establishment within the past 125 years. As noted by Gaston et al. (2008), many losses of species in PAs have been attributed to poor management, as recorded here. Approaches to land use and management within a PA can therefore be considered as a potential cause of biodiversity loss. In the New Forest, such losses have occurred because of conflicts between different management objectives, relating to the relative values accorded to timber, deer, livestock, and biodiversity conservation, which have changed over time. The land management activities responsible for species loss, such as drainage, scrub clearance, and plantation establishment, were primarily undertaken to support timber production, or to increase forage for livestock. Conversely, cessation of such management approaches in the interests of biodiversity conservation would be associated with opportunity costs in terms of reduced timber and livestock production.

From a systems perspective, the New Forest can be considered as being maintained in a dynamic equilibrium, with individual plant communities continually being transformed into others, primarily as a result of grazing pressure and succession (Tubbs
2001). It also demonstrates many of the features of coupled social-ecological systems identified by Liu et al. (2007), including reciprocal feedback loops, thresholds, spatiotemporal heterogeneity, and effects of historical legacies on current conditions. For example, the system underwent significant transitions in governance and management in 1877 and 1971 as a result of major crises, the consequences of which are still evident today (Tubbs 2001, Newton 2010a). There is also some evidence that the dynamics of the system are linked to adaptive cycles at multiple scales (Gunderson and Holling 2002, Anderies et al. 2006). For example, Vera (2000) has suggested that vegetation dynamics are essentially cyclic, driven by grazing pressure (Appendix 3), although this still requires rigorous testing (Newton et al. 2010a). Patterns of disturbance have been highly dynamic over time, as illustrated by the pronounced variation in grazing pressure, leading to vegetation changes at the local scale. At the landscape scale, however, the system appears to have been remarkably stable (Tubbs 2001), which must have supported the maintenance of biodiversity. The New Forest therefore provides evidence of cross-scale connections, as well as an ability to absorb disturbance and reorganize while maintaining structure and function, which according to Folke (2006) and Walker et al. (2006) are key elements of social-ecological resilience. The long-term maintenance of the system, despite its internal dynamics and external shocks, highlights its adaptive capacity (Smit and Wandel 2006).

In this context, the recent changes that have occurred in commoning activities are particularly informative. Although depasturing of grazing animals continues, other traditional uses of common land have declined in the New Forest during the past century, as they have in many other areas (Appendix 2 ). Since 1949, the cutting and burning of vegetation has largely been undertaken by the site's managers (the Forestry Commission) rather than by commoners. This highlights how disturbance processes have been maintained despite a change in the role of different actors. Analyses of the economics of commoning consistently conclude that it generates little profit (Appendix 2). Those who engage in commoning today do so primarily for social or traditional reasons, rather than economic ones as they did in the past (Tubbs 2001). The current resilience of the system is dependent on this shift from economic to socio-cultural values as the prime motivation for maintaining traditional land use patterns.

The New Forest can be considered to comprise a set of subsystems relating to different land uses, including timber, deer, livestock, recreation, and biodiversity conservation. Each of these uses has demonstrated its own dynamics over time, in response to changing policy objectives and governance. However, these subsystems are also linked; for example, the collapse in deer numbers following 1851 facilitated expansion of the timber resource, which resulted in a reduction in land available for livestock and led to both 
positive and negative impacts on biodiversity. In line with previous research, the governance system in this case study could potentially be considered as an adaptive cycle (Gunderson et al. 1995). In this context, the sudden shift away from timber production precipitated by the crisis of the late 1960s could be viewed as a collapse in the timber production subsystem, leading to a transformation in management objectives toward biodiversity conservation. In common with analysis of other forest systems, this example illustrates the importance of national policy as a key driver of adaptive-cycle dynamics, with nonlinear policy shifts driving similar dynamics in linked subsystems (Baskerville 1995, Beier et al. 2009).

The potential for further sudden shifts in governance is illustrated by the recent attempt by the UK Government to sell off large parts of the national forest estate (UK Parliament 2010), which could have led to major changes in how the New Forest is managed. These plans were dropped in early 2011, in response to a major initiative by campaigning groups. While demonstrating some parallels with previous campaigns, a key difference was one of size: an on-line petition developed by the campaigning group 38 Degrees (http://38degrees.org.uk/ ) attracted more than half a million signatories. Achieved through the highly effective use of social media websites, this illustrates how the formation of alliances has been transformed by the internet, which is thereby contributing to the resilience of social-ecological systems.

\section{CONCLUSIONS}

There has recently been a shift from a model of PA management that removes humans from the land, to one that involves local communities in the process of conservation management (Phillips 2003, Bonham et al. 2008). PAs can therefore increasingly be viewed as coupled social-ecological systems. In order to be effective, management of PAs must address the factors responsible for biodiversity loss. As illustrated here, this can be achieved where there is a coincidence between the activities of local people and the mitigation of such factors. In order to be effective, both in terms of maintaining biodiversity as well as in maintaining human livelihoods, PAs also need to be resilient. The example of the New Forest, an English PA in which traditional land uses have been maintained for more than 900 years, despite major environmental and socioeconomic changes, has been provided here. This example provides insights into how resilience of coupled social-ecological systems can be achieved over long timescales, which has implications for the management of other PAs worldwide.

The New Forest demonstrates that over the long term, coupled social-ecological systems can be resilient to major internal and external shocks, including climate change, mass human mortality, war, and profound political and socioeconomic changes in society. While the area experienced a wide variety of different shocks over the past nine centuries, those relating to governance had the greatest impact on the reserve itself. Although local people were successful at defending their traditional land use rights throughout most of the past 900 years, at times of severe crisis they required alliances with external partners, including academics, naturalists, and the general public. This provides an example of how the development of an "advocacy coalition", involving actors from different interest groups and organizations, can be effective in producing a change in policy (Sabatier 1998). In addition, this example highlights the value of social networks as a source of resilience in social-ecological systems (Hahn et al. 2008).

The development of such alliances depended critically on amenity use of the PA by visitors to the area, which in turn was greatly supported by the development of transport infrastructure. Without this improvement in access, and consequent growth of public interest and support, this PA would probably not have survived the $19^{\text {th }}$ century. This highlights the importance of tourism and recreation to PAs. Encouraging visitor access may be crucial to the effectiveness and resilience of PAs, by building a network or coalition of people prepared to defend them against external pressures.

This social-ecological system has been both highly dynamic (e.g., in disturbance regime), but also relatively stable (e.g., in land use patterns), demonstrating key features of an adaptive system. However, the factors underpinning this adaptability and resilience have changed over time. For example, traditional land uses now persist primarily for social and cultural reasons rather than for economic ones, as in the past. To be effective over the long term, social structures and institutions as well as environmental processes require adaptive capacity. As illustrated here, this is related to the existence of social networks, and their role in building social capital (Hahn et al. 2008). In addition, adaptive capacity can potentially be strengthened by institutional diversity and by the associated diversity of management options (Norberg et al. 2008). Increasingly, this diversity is likely to be crucial to the future resilience of the New Forest, which like many other PAs, is being subjected to intensifying pressures associated with a massive increase in recreational use and the effects of climate change (Newton 2010a).

\section{RESPONSES TO THIS ARTICLE}

Responses to this article are invited. If accepted for publication, your response will be hyperlinked to the article. To submit a response, follow this link. To read responses already accepted, follow this link.

\section{LITERATURE CITED}

Anderies, J. M., B. H. Walker, and A. P. Kinzig. 2006. Fifteen weddings and a funeral: case studies and resilience-based management. Ecology and Society 11(1):21. [online] URL: http://www.ecologyandsociety.org/vol11/iss1/art21/ 
Baskerville, G. L. 1995. The forestry problem: adaptive lurches of renewal. Pages 37-102 in L. H. Gunderson, C. S. Holling, and S. S. Light, editors. Barriers and bridges to the renewal of ecosystems and institutions. Columbia University Press, New York, New York, USA.

Bathe, G. 2010. Of commoners and kings. Landscape Archaeology and Ecology 8:25-38.

Beier, C., A. L. Lovecraft, and T. Chapin. 2009. Growth and collapse of a resource system: an adaptive cycle of change in public lands governance and forest management in Alaska. Ecology and Society 14(2):5. [online] URL: http://www.ecolo gyandsociety.org/vol14/iss2/art5/

Bengtsson, J., P. Angelstam, T. Elmqvist, U. Emanuelsson, C. Folke, M. Ihse, F. Moberg, and M. Nyström. 2003. Reserves, resilience and dynamic landscapes. Ambio 32 (6):389-396.

Bonham, C. A., E. Sacayon, and E. Tzi. 2008. Protecting imperiled "paper parks": potential lessons from the Sierra Chinajá, Guatemala. Biodiversity and Conservation 17:1581-1593. http://dx.doi.org/10.1007/s10531-008-9368-6

Brand, F. 2009. Critical natural capital revisited: ecological resilience and sustainable development. Ecological Economics 68:605-612. http://dx.doi.org/10.1016/j.ecolecon. 2008.09.013

Brazdil, R., C. Pfister, H. Wanner, H. von Storch, and J. Luterbacher. 2005. Historical climatology in Europe-the state of the art. Climate Change 70:363-430. http://dx.doi.org/10.1 007/s10584-005-5924-1

Brooks, T. M., S. J. Wright, and D. Sheil. 2009. Evaluating the success of conservation actions in safeguarding tropical forest biodiversity. Conservation Biology 23(6):1448-1457. http://dx.doi.org/10.1111/j.1523-1739.2009.01334.x

Butchart, S. H. M., M. Walpole, B. Collen, A. van Strien, J. P. W. Scharlemann, R. E. A. Almond, J. E. M. Baillie, B. Bomhard, C. Brown, J. Bruno, K. E. Carpenter, G. M. Carr, J. Chanson, A. M. Chenery, J. Csirke, N. C. Davidson, F. Dentener, M. Foster, A. Galli, J. N. Galloway, P. Genovesi, R. D. Gregory, M. Hockings, V. Kapos, J.-F. Lamarque, F. Leverington, J. Loh, M.A. McGeoch, L. McRae, A. Minasyan, M. Hernández Morcillo, T. E. E. Oldfield, D. Pauly, S. Quader, C. Revenga, J. R. Sauer, B. Skolnik, D. Spear, D. StanwellSmith, S. N. Stuart, A. Symes, M. Tierney, T. D. Tyrrell, J.C. Vié, and R. Watson. 2010. Global biodiversity: indicators of recent declines. Science 328(5982):1164-1168. http://dx.do i.org/10.1126/science. 1187512

Campbell, B. M. S. 2010. Nature as historical protagonist: environment and society in pre-industrial England. Economic
History Review 63(2):281-314. http://dx.doi.org/10.1111/j.14 68-0289.2009.00492.x

Carey, C., N. Dudley, and S. Stolton. 2000. Squandering paradise?. WWF International, Gland, Switzerland.

Carpenter, S. R., F. Westley, and M. G. Turner. 2005. Surrogates for resilience of social-ecological systems. Ecosystems 8:941-944. http://dx.doi.org/10.1007/s10021-005 $\underline{-0170-\mathrm{y}}$

Chape, S., J. Harrison, M. Spalding, and I. Lysenko. 2005. Measuring the extent and effectiveness of protected areas as an indicator for meeting global biodiversity targets. Philosophical Transactions of the Royal Society B 360:443-455. http://dx.doi.org/10.1098/rstb.2004.1592

Craigie, I. D., J. E. M. Baillie, A. Balmford, C. Carbone, B. Collen, R. E. Green, and J. M. Hutton. 2010. Large mammal population declines in Africa's protected areas. Biological Conservation 143:2221-2228. http://dx.doi.org/10.1016/j.bio con.2010.06.007

DeFries, R., A. Hansen, A. C. Newton, and M. C. Hansen. 2005. Increasing isolation of protected areas in tropical forests over the past twenty years. Ecological Applications 15:19-26. http://dx.doi.org/10.1890/03-5258

Estes, R. D., J. L. Atwood, and A. B. Estes. 2006. Downward trends in Ngorongoro Crater ungulate populations 1986-2005: conservation concerns and the need for ecological research. Biological Conservation 131:106-120. http://dx.doi.org/10.10 16/j.biocon.2006.02.009

Fitter, R. S. R. 1959. The ark in our midst. Collins, London, UK.

Folke, C. 2006. Resilience: The emergence of a perspective for social-ecological systems analyses. Global Environmental Change 16:253-267. http://dx.doi.org/10.1016/j.gloenvcha.20 $\underline{06.04 .002}$

Gaston, K. J., S. F. Jackson, L. Cantú-Salazar, and G. CruzPiñón. 2008. The ecological performance of protected areas. Annual Review of Ecology, Evolution, and Systematics 39:93113. http://dx.doi.org/10.1146/annurev.ecolsys.39.110707.173529

Gunderson, L. 2000. Ecological resilience - in theory and application. Annual Review of Ecology and Systematics 31:425-439. http://dx.doi.org/10.1146/annurev.ecolsys.31.1.425

Gunderson, L. H., and C. S. Holling, editors. 2002. Panarchy: understanding transformations in human and natural systems. Island Press, Washington, D.C., USA.

Gunderson, L. H., C. S. Holling, and S. S. Light, editors. 1995. Barriers and bridges to the renewal of ecosystems and 
institutions. Columbia University Press, New York, New York, USA.

Hahn, T., L. Schultz, C. Folke, and P. Olsson. 2008. Social networks as sources of resilience in social-ecological systems. Pages 119-148 in G. Norberg, and G. S. Cumming, editors. Complexity theory for a sustainable future. Columbia University Press, New York, USA.

Hockings, M., S. Stolton, F. Leverington, N. Dudley, and J. Courrau. 2006. Evaluating effectiveness: a framework for assessing management effectiveness of protected areas. Second edition. International Union for the Conservation of Nature (IUCN), Gland, Switzerland, and Cambridge, UK. http://dx.doi.org/10.2305/IUCN.CH.2006.PAG.14.en

Holling, C. S. 1973. Resilience and stability of ecological systems. Annual Review of Ecology and Systematics 4:1-23. http://dx.doi.org/10.1146/annurev.es.04.110173.000245

Kenchington, F. E. 1944. The commoner's New Forest. Hutchinson and Company, London, UK.

Liu, J., T. Dietz, S. R. Carpenter, M. Alberti, C. Folke, E. Moran, A. N. Pell, P. Deadman, T. Kratz, J. Lubchenco, E. Ostrom, Z. Ouyang, W. Provencher, C. L. Redman, S. H. Schneider, and W. W. Taylor. 2007. Complexity of coupled human and natural systems. Science 317:1513-1516. http://dx .doi.org/10.1126/science.1144004

Lockwood, M., G. L. Worboys, and A. Kothari, editors. 2006. Managing protected areas. A global guide. Earthscan, London, UK.

Lovegrove, R. 2007. Silent fields. The long decline of a nation's wildlife. Oxford University Press, Oxford, UK.

Margoluis, R., C. Margoluis, K. Brandon, and N. Salafsky. 2000. In good company: effective alliances for conservation. Biodiversity Support Program, Washington, D.C., USA.

Nagendra, H. 2008. Do parks work? Impact of protected areas on land cover clearing. Ambio 37:330-337. http://dx.doi.org/1 $\underline{0.1579 / 06-R-184.1}$

Natural England. 2010. Lost life: England's lost and threatened species. Natural England, Peterborough, UK.

Naughton-Treves, L., M. Holland, and K. Brandon. 2005. The role of protected areas in conserving biodiversity and sustaining local livelihoods. Annual Review of Environment and Resources 30:219-252. http://dx.doi.org/10.1146/annurev. energy.30.050504.164507

Newmark, W. D. 1995. Extinction of mammal populations in western American national parks. Conservation Biology 9:512-526. http://dx.doi.org/10.1046/j.1523-1739.1995.09030512. $\underline{\mathrm{X}}$

Newton, A. C., editor. 2010a. Biodiversity in the New Forest. Pisces, Newbury, Hampshire, UK.
Newton, A. C. 2010b. Synthesis: status and trends of biodiversity in the New Forest. Pages 218-228 in A. C. Newton, editor. Biodiversity in the New Forest. Pisces, Newbury, Hampshire, UK.

Newton, A. C., E. Cantarello, G. Myers, S. Douglas, and N. Tejedor. 2010. The condition and dynamics of New Forest woodlands. Pages 132-147 in A. C. Newton, editor. Biodiversity in the New Forest. Pisces, Newbury, Hampshire, UK.

Norberg, J., J. Wilson, B. Walker, and E. Ostrom. 2008. Diversity and resilience of social-ecological systems. Pages 46-79 in G. Norberg, and G. S. Cumming, editors. Complexity theory for a sustainable future. Columbia University Press, New York, USA.

Normile, D. 2010. U.N. biodiversity summit yields welcome and unexpected progress. Science 330:742-743. http://dx.doi. org/10.1126/science.330.6005.742

Oates, M. R. 1996. The demise of butterflies in the New Forest. British Wildlife 7(4):205-216.

Parks, S. A., and A. H. Harcourt. 2002. Reserve size, local human density, and mammalian extinctions in US protected areas. Conservation Biology 16(3):800-808. http://dx.doi.org /10.1046/j.1523-1739.2002.00288.x

Pasmore, A. H. 1977. Verderers of the New Forest: a history of the New Forest 1877-1977. Pioneer, Beaulieu, UK.

Peterken, G. F., and C. R. Tubbs. 1965. Woodland regeneration in the New Forest, Hampshire, since 1650. Journal of Applied Ecology 2(1):159-170. http://dx.doi.org/1 $\underline{0.2307 / 2401702}$

Phillips, A. 2003. Turning ideas on their head- the new paradigm for protected areas. The George Wright Forum 20 (2):8-32.

Putman, R. J. 1986. Grazing in temperate ecosystems. Large herbivores and the ecology of the New Forest. Croom Helm, London, UK, and Sydney, Australia.

Rand, M., and C. Chatters. 2010. Vascular plants. Pages 84-111 in A. C. Newton, editor. Biodiversity in the New Forest. Pisces, Newbury, Hampshire, UK.

Rodrigues, A. S. L., S. J. Andelman, M. I. Bakarr, L. Boitani, T. M. Brooks, R. M. Cowling, L. D. C. Fishpool, G. A. B. Fonseca, K. J. Gaston, M. Hoffmann, J. S. Long, P. A. Marquet, J. D. Pilgrim, R. L. Pressey, J. Schipper, W. Sechrest, S. N. Stuart, L. G. Underhill, R. W. Waller, M. E. J. Watts, and X. Yan. 2004. Effectiveness of the global protected area network in representing species diversity. Nature 428:640-643. http://dx.doi.org/10.1038/nature02422 
Sabatier, P. A. 1998. The advocacy coalition framework: revisions and relevance for Europe. Journal of European Public Policy 5:98-130.

Salafsky, N., R. Margoluis, K. Redford, and J. Robinson. 2002. Improving the practice of conservation: a conceptual framework and research agenda for conservation science. Conservation Biology 16:1469-1479. http://dx.doi.org/10.1046/ j.1523-1739.2002.01232.x

Short, C. 2008. The traditional commons of England and Wales in the twenty-first century: meeting new and old challenges. International Journal of the Commons 2 (2):192-221. URL: http://www.thecommonsjournal.org/index. php/ijc/article/viewArticle/47/41. Accessed 17.6.2010

Small, D., and G. M. Haggett. 1972. A study of broadleaved woodland changes and natural regeneration of broadleaves in the Ancient and Ornamental woodlands from 1867-1963. New Forest, Forestry Commission Management Plan 1972-1981 Appendix D. Forestry Commission, Lyndhurst, UK.

Smit, B., and J. Wandel. 2006. Adaptation, adaptive capacity and vulnerability. Global Environmental Change 16 (3):282-292. http://dx.doi.org/10.1016/j.gloenvcha.2006.03.008

Smith, J., and L. Burke. 2010. Managing the New Forest's Crown lands. Pages 212-217 in A. C. Newton, editor. Biodiversity in the New Forest. Pisces, Newbury, Hampshire, UK.

Snook, A. M. 1998. Birds of the New Forest. A visitor's guide. Centurion Books, Fordingbridge, Hants, UK.

Stagg, D. J. 1992. Silvicultural inclosure in the New Forest from 1850 to 1877. Proceedings of Hampshire Field Club Archaeological Society 48:143-59.

Sutherland, W. J. 2000. The Conservation Handbook. Research, Management and Policy. Blackwell Science, Oxford. UK. http://dx.doi.org/10.1002/9780470999356

Tubbs, C. R. 1968. The New Forest: an ecological history. David and Charles, Newton Abbot, UK.

Tubbs, C. R. 2001. The New Forest. History, ecology and conservation. New Forest Ninth Centenary Trust, Lyndhurst, UK.

UK Parliament. 2010. Public Bodies Bill. [online] URL: http ://www.publications.parliament.uk/pa/ld201011/ldbills/025/11025. i-ii.html

Vera, F. W. M. 2000. Grazing ecology and forest history. CABI, Wallingford, Oxford, UK. http://dx.doi.org/10.1079/9 $\underline{780851994420.0000}$

Walker, B., S. Carpenter, J. Anderies, N. Abel, G. Cumming, M. Janssen, L. Lebel, J. Norberg, G. D. Peterson, and R.
Pritchard. 2002. Resilience management in social-ecological systems: a working hypothesis for a participatory approach. Conservation Ecology 6(1):14. [online] URL: http://www.co nsecol.org/vol6/iss1/art14

Walker, B. H., L. H. Gunderson, A. P. Kinzig, C. Folke, S. R. Carpenter, and L. Schultz. 2006. A handful of heuristics and some propositions for understanding resilience in socialecological systems. Ecology and Society 11(1):13. [online] URL: http://www.ecologyandsociety.org/vol11/iss1/art13/

Yalden, D. 1999. The history of British mammals. T. \& A. D. Poyser, London, UK. 


\section{APPENDIX 1. Description of the New Forest.}

The New Forest is situated on the south coast of England in the counties of Hampshire and Wiltshire, immediately north of the River Solent, and between the conurbations of Bournemouth and Southampton (Longitude from $1^{\circ} 17^{\prime} 59^{\prime \prime}$ ' to $1^{\circ} 48^{\prime} 8^{\prime \prime}$ ' W, Latitude from 5042'19' ' to 51ㅇ'17' ' N) (Figure A1.1, A1.2). As noted by Tubbs (2001), the New Forest as an ecological system has developed under the influence of large, free-ranging herbivores, including deer as well as livestock. The present character of the New Forest is therefore strongly dependent on its history as a medieval hunting forest, and the survival of a traditional commoning system, which became formalised in late medieval times.

The "perambulation" of the Forest, encompassing some 37,907 ha, refers to the area within which Forest bye-laws apply, relating to the rights to pasture livestock on common land. Almost a quarter of this area consists of farmland and settlements, whereas around three-quarters are referred to as the 'Crown lands', reflecting their status as Royal Forest. The Crown lands include the Silvicultural Inclosures, which are designated for growing timber; unenclosed land, over which common rights prevail; and a number of privately owned farm holdings. The unenclosed Forest is referred to by Tubbs (2001) as the largest area of semi-natural vegetation in lowland Britain, and includes large tracts of heathland, valley mire and ancient pasture woodland, three habitats that are now fragmented and rare throughout lowland western Europe. With a total area of almost 20,000 ha, the unenclosed Forest includes around 3700 ha of oak, beech and holly woodland, 12,500 ha of heathland and acid grassland, and 2900 ha of valley mires and wet heath.

The New Forest National Park was designated in 2005 and extends over 57,100 ha (Chatters 2006), a larger area than that included within the perambulation (Figure A1.3). The conservation importance of the National Park is reflected in a variety of designations, with some 20 Sites of Special Scientific Interest, six Natura 2000 sites and two Ramsar Convention sites included at least partly within the Park boundaries (Chatters 2006). The National Park also includes extensive areas of common land that border the Crown lands but lie outside the perambulation. In total, about $50 \%$ of the land area of the Park is covered by unenclosed vegetation, which is collectively referred to as the 'Open Forest' (Chatters 2006), and in which livestock roam freely. In recent years, some 6000-7400 ponies, cattle, donkeys, pigs and sheep have been depastured on the Open Forest, which are owned by about 550 local people ("commoners") who possess commoning rights (Newton 2010).

\section{LITERATURE CITED}

Chatters, C. 2006. The New Forest - National Park status for a medieval survivor. British Wildlife (December 2006):110-119.

Newton, A. C. (editor). 2010. Biodiversity in the New Forest. Pisces Publications, Newbury, Hampshire.

Tubbs, C. R. 2001. The New Forest. History, ecology and conservation. New Forest Ninth Centenary Trust, Lyndhurst. 


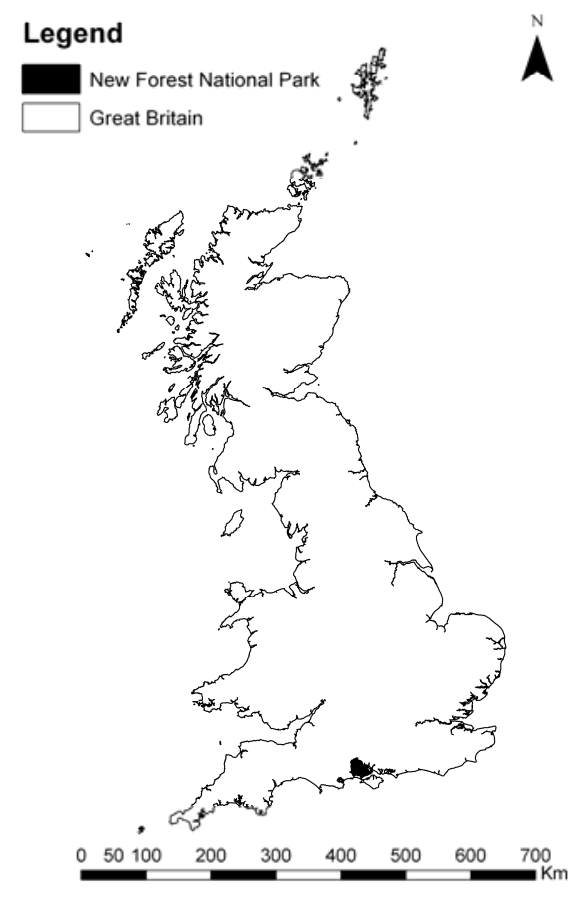

Figure A1.1. Map of the UK showing the location of the New Forest National Park.

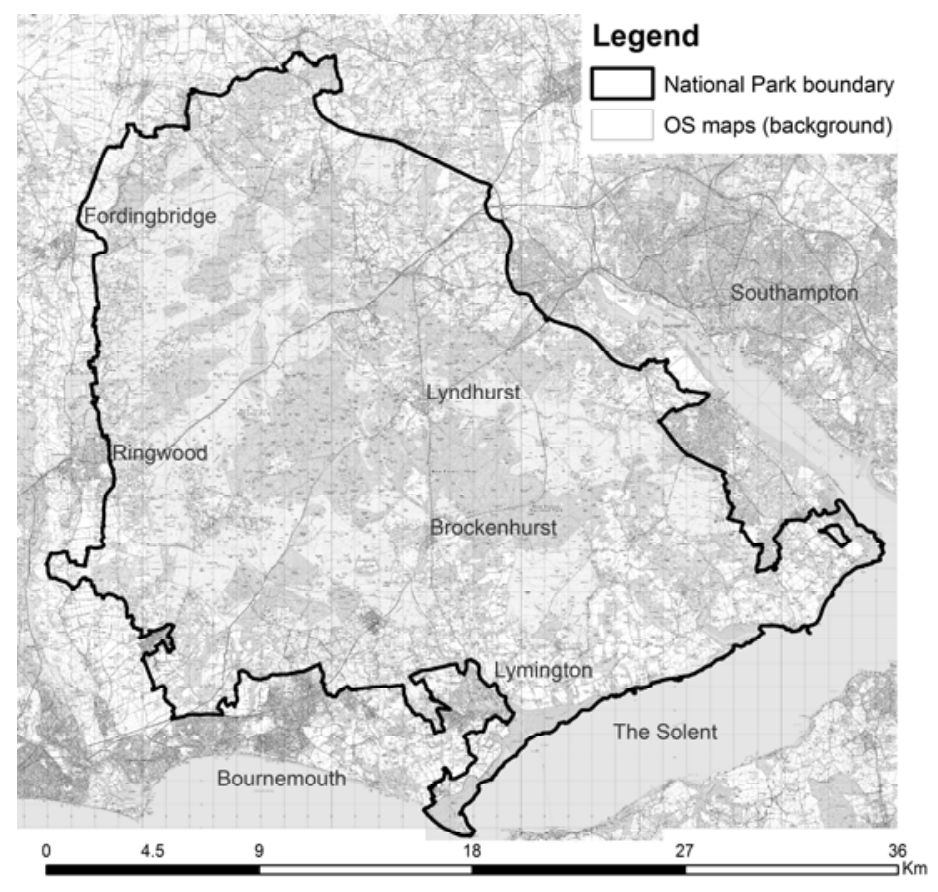

Figure A1.2. Map of the New Forest National Park, with the Park boundary overlaid on an Ordnance Survey (OS) map (@Crown Copyright/database right 2008. An Ordnance Survey/EDINA supplied service). 


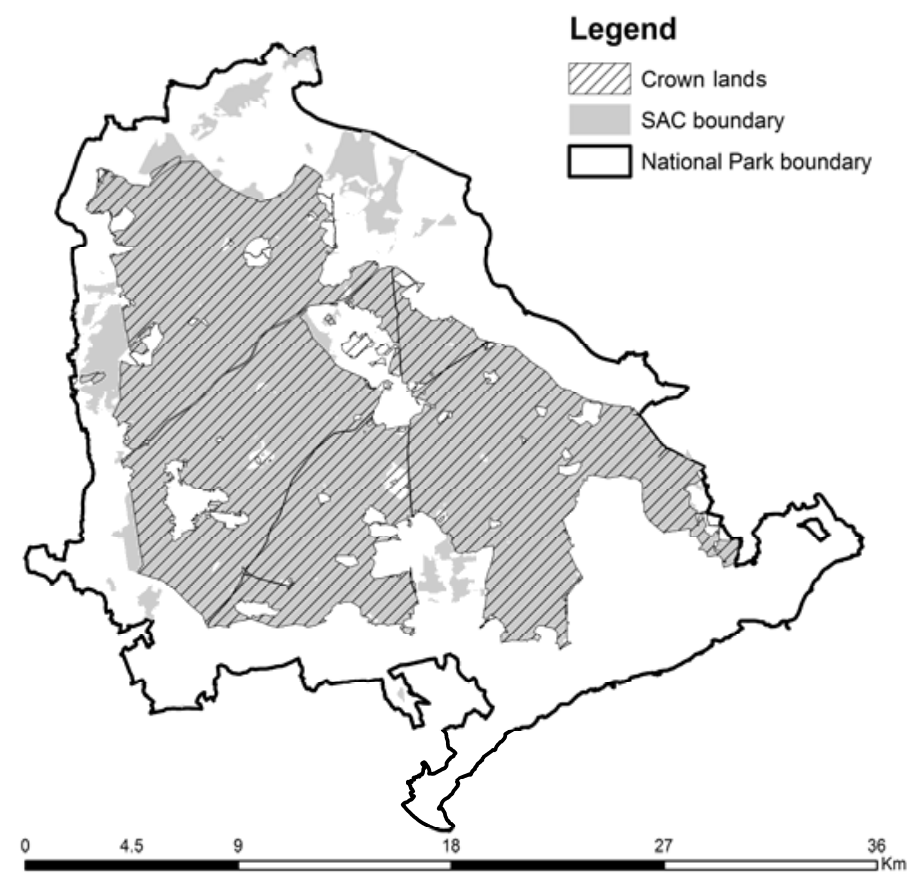

Figure A1.3. Crown lands, Special Area of Conservation (SAC) and National Park boundaries of the New Forest. The SAC is a Natura 2000 site, which essentially forms the core of the National Park. 


\section{APPENDIX 2. Traditional land uses: commoning in the New Forest}

\section{Common land in the UK}

In the UK, the term "common land" refers to land in private ownership, where traditional rights exist for people ("commoners") other than the landowner to use the land in specific ways. Such rights include the grazing of stock (common of pasture), digging of peat for fuel (turbery), collecting timber (estovers) and the taking of fish (piscary) (Aitchison et al. 2000, Short 2008). In recent years, common land has become the focus of increasing interest and concern. Specific issues relate to the decline of their economic functions, which could potentially threaten their existence; the development of multiple use patterns; their resilience to socio-economic and environmental change; and the policy responses required to sustain them in future (Short 2008).

The high value of common land for biodiversity conservation is widely acknowledged (Aitchison and Medcalf 1994, Aitchison et al. 2000). This value is illustrated by the fact that around 20\% of all Sites of Special Scientific Interest (SSSIs) in England include common land, and that 55\% of all commons contain SSSIs (Bathe 2005). Given their long history of human use, there is a widespread belief that the biodiversity value of common land is dependent on maintenance of traditional management approaches (Hindmarch and Pienkowski 2000). A recent review of pastoral commoning (i.e. the grazing of common land with livestock) in England suggested that there has been a significant reduction in the numbers of grazing livestock on commons over the last twenty years, and especially during the past decade (Pastoral Commoning Partnership 2009).

\section{Common land in the New Forest}

In the New Forest there were five "rights of common”, namely pasture (to allow grazing of cattle, ponies and donkeys), mast (to turn out pigs in the pannage season), turbary (to collect turf fuel), estovers (to collect fuel wood) and marl (to collect marl from recognized pits) (Tubbs 2001). Commoning is overseen by the Verderers Court, which includes five elected and five appointed Verderers whose role is to regulate the exercise of Rights of Common on the Forest. Their role is underpinned by New Forest Acts and byelaws that are enforced under their statutory responsibilities. The Verderers are supported by five Agisters, who oversee commoning activities across the Forest, including monitoring the condition and welfare of de-pastured animals, and organising the annual "drifts" when the animals are rounded up and marked (The Pastoral Commoning Partnership 2009). Annual fees are paid to the Verderers for all animals depastured on the Forest. The New Forest is unusual in that grazing numbers are officially unrestricted, but are limited to those individuals whose properties have the right to pasture attached.

As a result of commoning activities, the New Forest has been subjected to a number of forms of anthropogenic disturbance, which have varied in intensity over time. While grazing of livestock is today the most significant, other traditional uses included collection of turf and peat for fuel, and harvesting of heathland plants (such as gorse, 
heather and bracken) for fodder, thatch and bedding. Burning of heathland was also carried out to provide fresh regrowth for livestock (Tubbs 2001). In Medieval times, these uses were intensive, but as noted in the main text, they declined in the $19^{\text {th }}$ and $20^{\text {th }}$ centuries, particularly after World War II, representing a shift away from subsistence agriculture. Since then, agricultural policies and the development of mass marketing of agricultural produce have favoured large farms at the expense of smallholdings, which have declined nationally. The price of land and housing has increased markedly in the New Forest in recent decades, as the area has increasingly been colonized by incomers. Today, the use of common land to pasture livestock is largely a management option for farms, rather than a central component of the agricultural economy as it once was (Tubbs 2001).

The economics of commoning, and its future prospects, have been the subject of a recent review (The New Forest Commoning Review Group 2007). This highlighted the poor economic returns from commoning, and suggested that this is undermining its long term sustainability. Yet the number of people depasturing animals in the Forest actually increased by 50\% from 1987 to 2007 (Pastoral Commoning Partnership 2009), despite the lack of a significant economic incentive. For many commoners today, depasturing livestock on the Forest is primarily undertaken to continue family traditions and as a social habit, rather than to generate significant revenue. Participation in the social occasions associated with commoning therefore now outweigh profit as a motive to engage in commoning activities (Tubbs 2001). This also accounts for the continual increase in the number of ponies depastured in recent decades (see Figure 2, main text). The high social and cultural value of commoning therefore confers a degree of resilience to the system.

\section{LITERATURE CITED}

Aitchison, J., K. Crowther, M. Ashby, and L. Redgrave. 2000. The common lands of England. A biological survey. Rural Surveys Research Unit, University of Wales, Aberystwyth. Department of the Environment, Transport and the Regions, London.

Aitchison, J.W. and K. A. Medcalf. 1994. Common land and conservation: biological surveys in England and Wales - A synthesis. Rural Surveys Research Unit, Department of Geography, University of Wales, Aberystwyth.

Bathe, G. 2005. Natural England and common land. Proceedings of the 5th National Seminar on Common Land and Village Greens. Countryside and Community Research Unit, University of Gloucestershire, Cheltenham.

Hindmarch, C. and M. Pienkowski, editors. 2000. Land management: the hidden costs. Blackwell Science, Oxford, for the British Ecological Society, London.

Short, C. 2008. The traditional commons of England and Wales in the twenty-first century: meeting new and old challenges. International Journal of the Commons 2, 2. URL: http://www.thecommonsjournal.org/index.php/ijc/article/viewArticle/47/41. Accessed 17.6.2010. 
The New Forest Commoning Review Group. 2007. New Forest Commoning Review 2007. A commoner led review of current issues relating to the practice of commoning within the New Forest National Park. New Forest National Park Authority, Lymington.

The Pastoral Commoning Partnership. 2009. Trends in pastoral commoning in England. Natural England Commissioned Report NECR001.

http://naturalengland.etraderstores.com/naturalenglandshop/NECR001 Downloaded 17.6.10

Tubbs, C. R. 2001. The New Forest. History, ecology and conservation. New Forest Ninth Centenary Trust, Lyndhurst. 


\section{APPENDIX 3. Disturbance and vegetation dynamics}

In addition to the governance-related shocks referred to in the main text, the New Forest has also been subjected to major disturbance events that are environmental in origin. For example, in 1980-83 there was a population explosion of a number of moth species (e.g. Erannis defoliaria and Tortrix viridiana), which caused widespread oak defoliation (Tubbs 2001). In the decade 1974-1984, the area experienced a sequence of hot, dry summers, which led to the death of many hundreds of mature trees, and desiccation of wetland habitats.

In the past two decades climate has continued to change, with 10 of the 12 warmest years recorded in the last 350, with winters becoming wetter and summers slightly drier (Jenkins et al. 2007). The most striking impact has been on the health of beech (Fagus sylvatica), which has continued to decline in the New Forest as in other areas of southern England (Power et al. 1995). A number of beech stands have undergone canopy collapse as a result of the effects of drought and storm damage, leading to changes in woodland structure and composition (Newton et al. 2010). As noted by Tubbs (2001), the New Forest experienced major wind storms in 1987 and 1990, which contributed to the recent high mortality of mature trees. The evidence of stand collapse in beech supports the suggestion of Gunderson (2000), that systems approaching limits to conservative growth may be brittle, and particularly susceptible to disturbance.

The impact of disturbance on vegetation dynamics has been the focus of some research interest (Newton et al. 2010). The theory developed by Vera (2000), which examines the potential role of vertebrate herbivory in the dynamics of European woodlands, has been particularly influential. The theory is based on the idea that the original vegetation of the lowlands of Europe was a park-like landscape, in which successional processes were determined by large herbivorous mammals and birds (such as the jay) that act as seed dispersal agents (Figure A3.1). Specialised grass eaters, such as wild cattle and wild horses, produced grassland vegetation in which thorny shrubs become established, into which species of tree may become established. These are then protected from herbivory, and develop into groves of trees, which advance into the grassland as the thorny shrubs advance. Regeneration of trees within the grove is prevented because of shade, and because of herbivory, as animals are able to enter the grove as it matures. As a result, the forest grove eventually degenerates into grassland, and the cycle begins again (Figures A3.1-A3.5).

Vera (2000) considered the New Forest in detail, citing it as evidence of support of this theory. However, the theory has not been rigorously tested, and therefore doubts remain regarding its applicability to the New Forest (Newton et al. 2010). If the theory is correct, it may provide a basis for adaptive cycles of vegetation dynamics within the New Forest.

\section{LITERATURE CITED}

Gunderson, L. 2000. Ecological resilience - in theory and application. Annual Review of Ecology and Systematics 31:425-439. 
Jenkins, G. J., M. C. Perry, and M. J. O. Prior. 2007. The climate of the United Kingdom and recent trends. Met Office Hadley Centre, Exeter, UK.

Newton, A. C., E. Cantarello, G. Myers, S. Douglas, and N. Tejedor. 2010. The condition and dynamics of New Forest woodlands. Pages 132-147 in A. C. Newton, editor Biodiversity in the New Forest. Pisces Publications, Newbury, Hampshire.

Power, S. A., M. R. Ashmore, and K. A. Ling. 1995. Recent trends in beech tree health in southern Britain and the influence of soil type. Water, Air, and Soil Pollution 85(3):1293-1298.

Tubbs, C. R. 2001. The New Forest. History, ecology and conservation. New Forest Ninth Centenary Trust, Lyndhurst.

Vera, F. W. M. 2000. Grazing ecology and forest history. CABI Publishing, Wallingford, Oxford, UK.

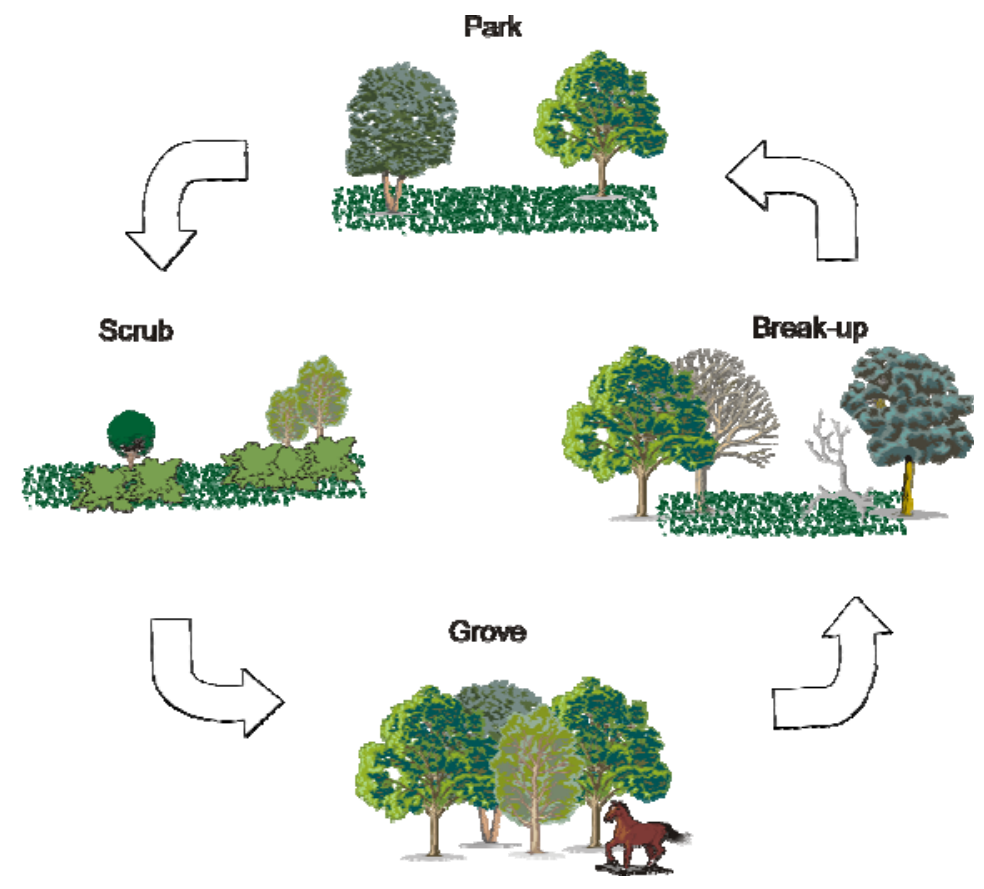

Figure A3.1. Schematic diagram of Vera's cyclical theory of vegetation turnover (after Newton et al. 2010, based on Vera 2000). The Park phase is a largely open landscape with a thin scatter of trees left from the previous grove; vegetation mainly grassland or heath species. In the Scrub phase, spread of thorny shrubs excludes herbivores; young trees grow up with the shrubs and eventually overtop them. In the Grove phase, which is the tree-dominated phase of the cycle, a closed tree canopy shades out the shrubs, and herbivores return, preventing regeneration. In the Break-up phase, the canopy opens out as trees die; vegetation shifts from woodland to grassland species. 


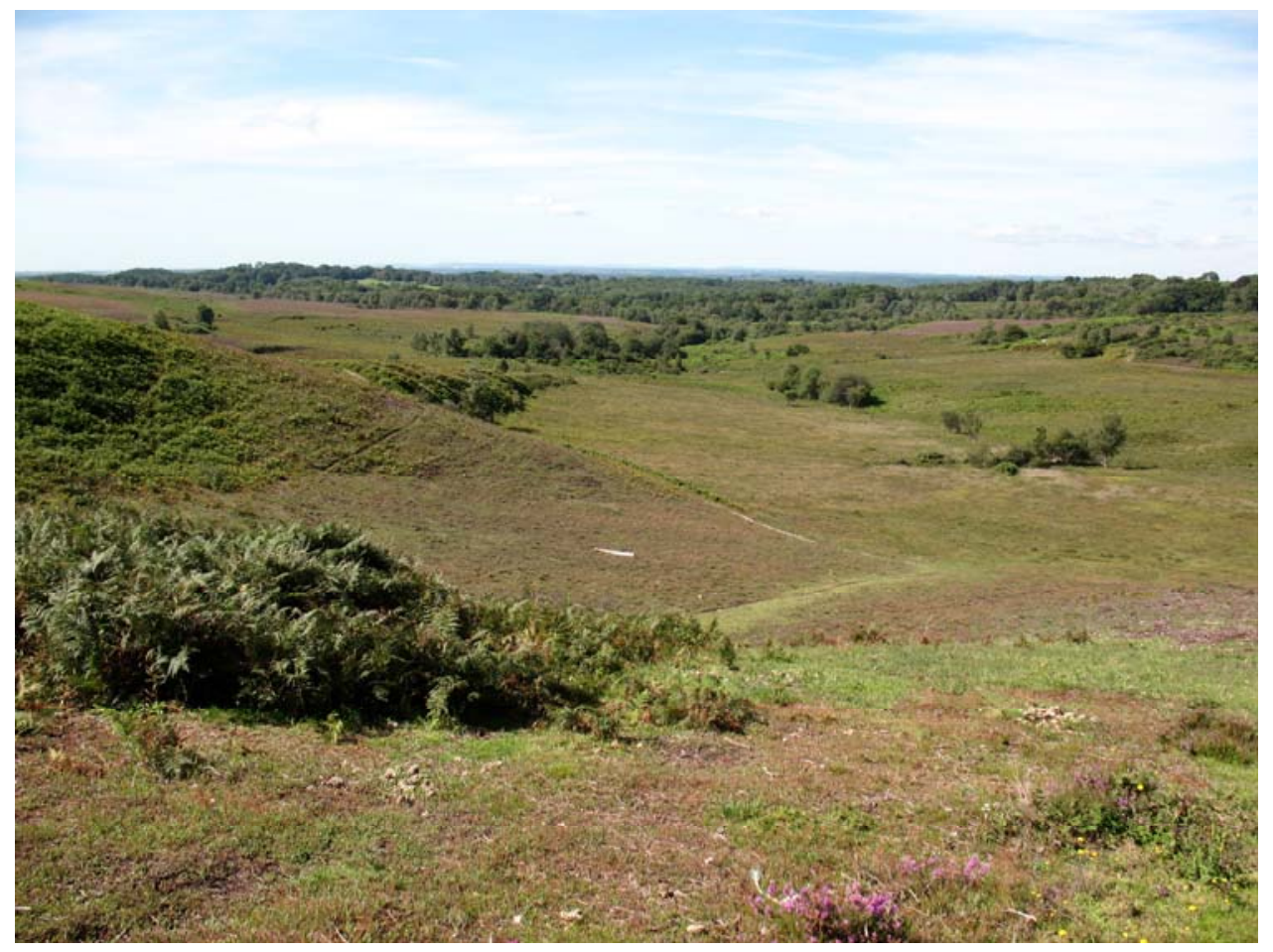

Figure A3.2. Landscape of the New Forest illustrating a typical mosaic of heathland, grassland and woodland communities.

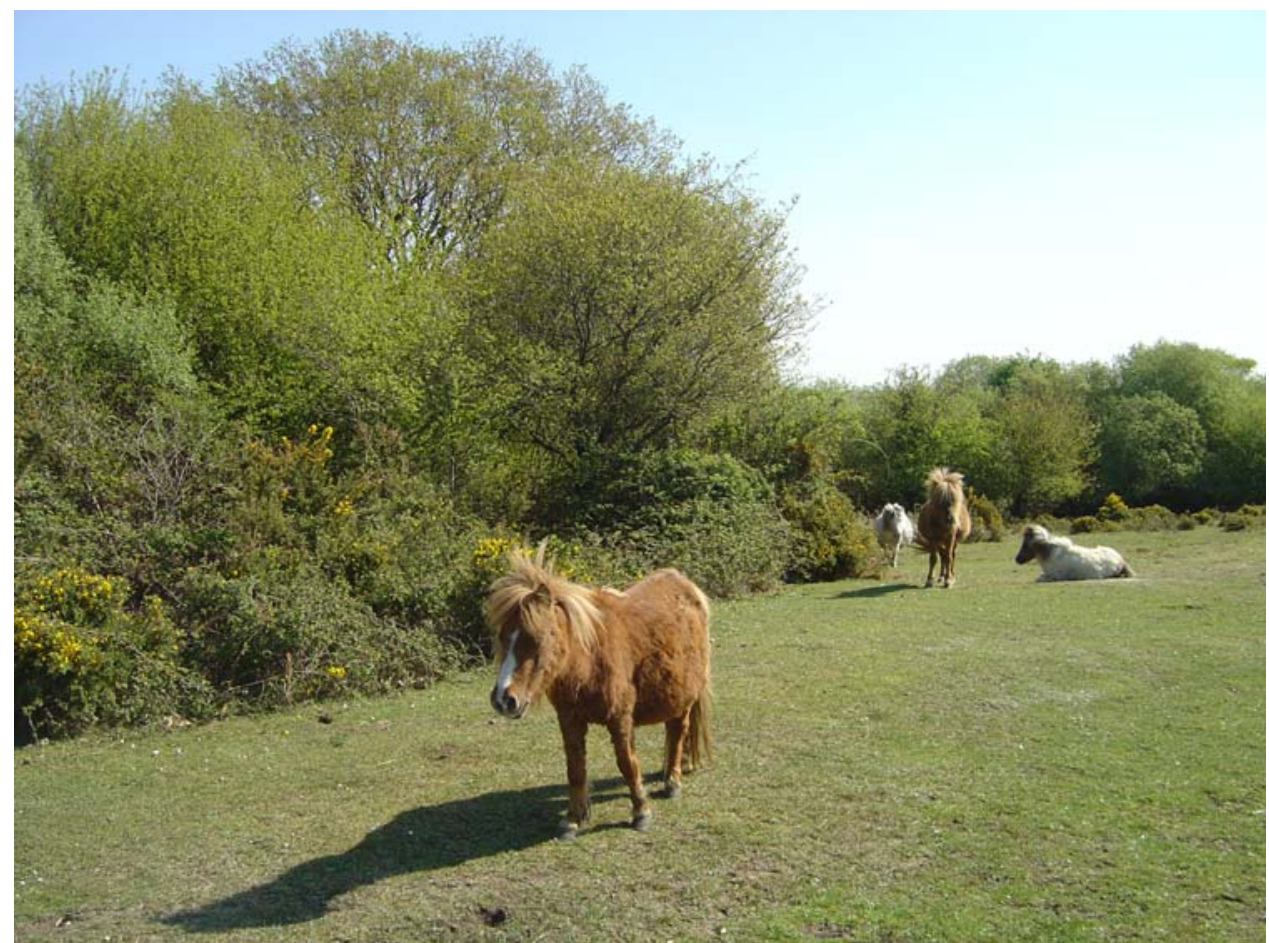

Figure A3.3. Interface between scrub and grassland communities, with New Forest ponies. Tree establishment is visible within the thorny scrub, in accordance with Vera's theory. 


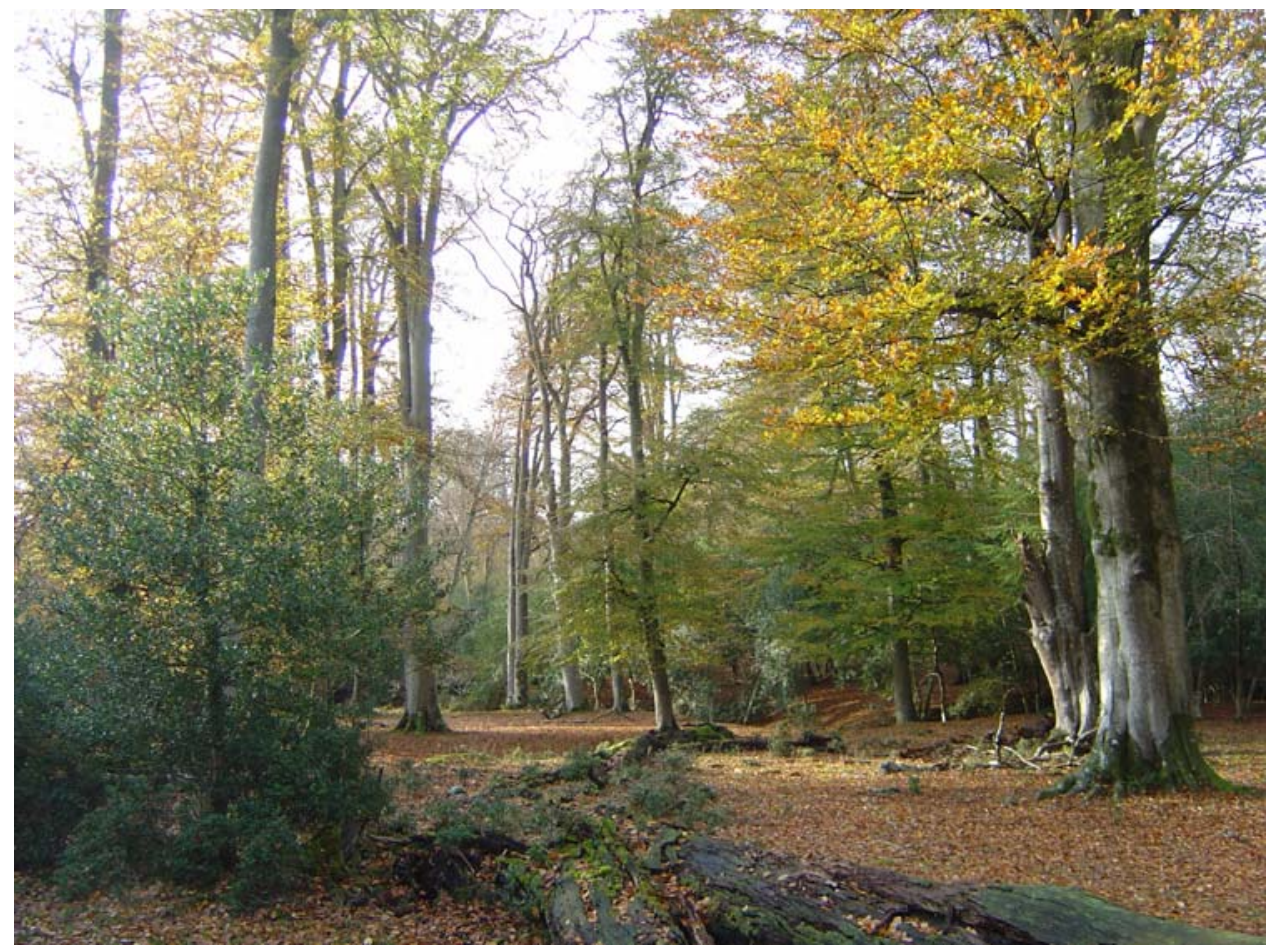

Figure A3.4. Wood Crates, one of the ancient woodlands of the New Forest, of exceptional value as habitat for wildlife.

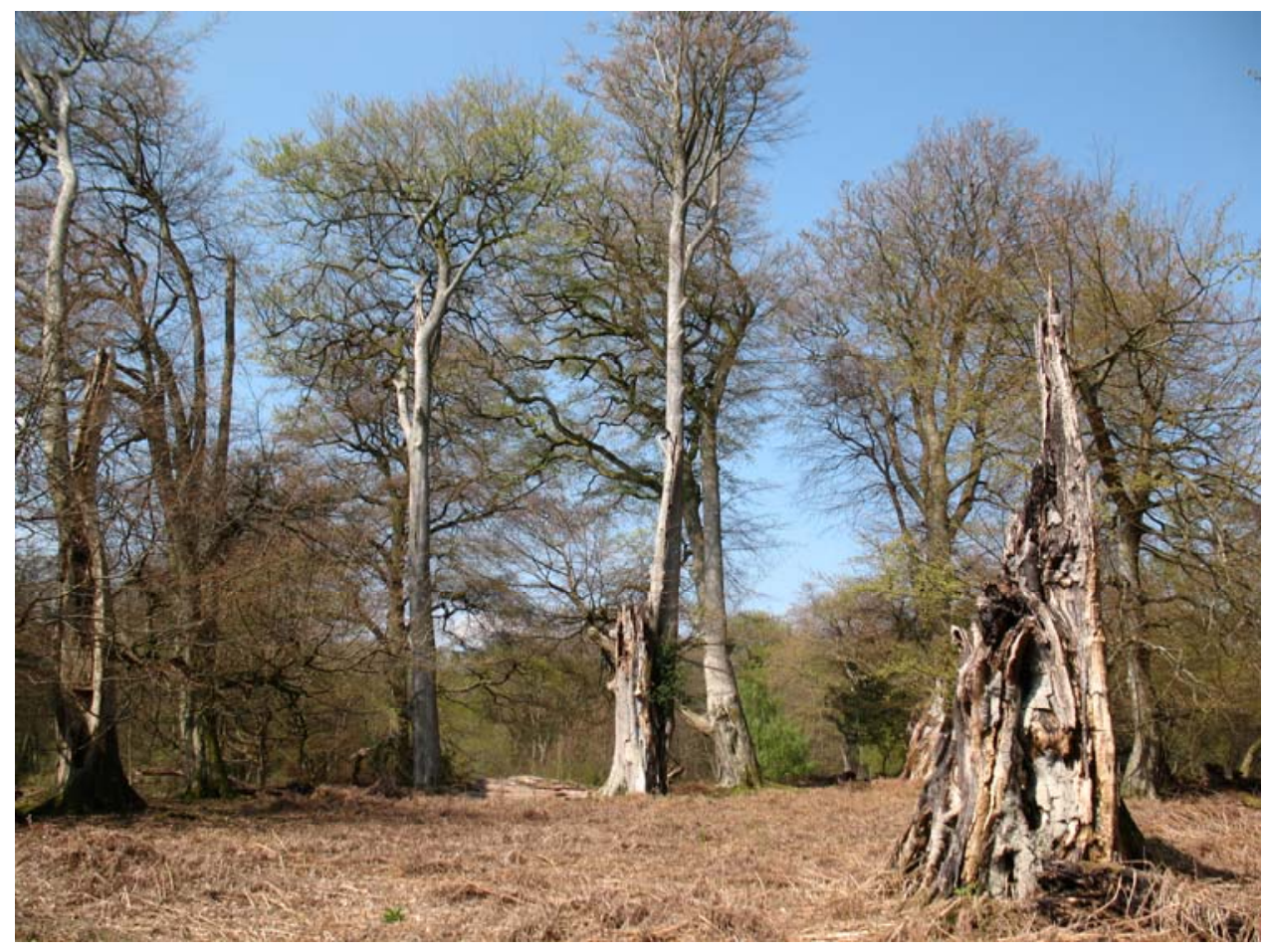

Figure A3.5. Mark Ash wood, illustrating the canopy collapse that has occurred in some New Forest beechwoods, supporting elements of Vera's theory. 